\title{
Mathematical model of the energy consumption calculation during the pine sawn wood (Pinus sylvestris L.) drying process
}

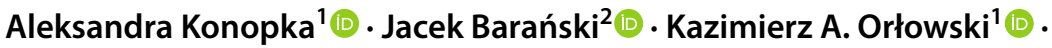 \\ Dariusz Mikielewicz ${ }^{2}$ (D) - Ladislav Dzurenda ${ }^{3}$ (i)
}

Received: 14 October 2020 / Accepted: 20 February 2021 / Published online: 17 March 2021

(c) The Author(s) 2021

\begin{abstract}
The article presents a modification of the existing mathematical model to calculate energy consumption during conventional drying process. Apart from energy consumption, the model permits to estimate the time of high-temperature drying process. The drying medium is air and superheated steam mixture. The obtained calculation results were compared with conducted experimental tests of drying square-edged sawn sapwood timber (Pinus sylvestris L.). The pine sawn wood samples were dried according to three different drying modes, namely mild, normal and intense. The experiments were performed in a semi-industrial scale drying chamber. On the basis of the experimental research available, existing mathematical models of drying wood have been improved. The developed model included the following changes: a different drying time for each mode and type of drying medium (moisturized air or air and superheated steam mixture). The use of an intensive drying mode significantly reduced the drying process time. The developed mathematical model revealed that the energy consumption of the drying process increases with the intensity of the mode used.
\end{abstract}

Aleksandra Konopka

aleksandra.konopka@pg.edu.pl

1 Faculty of Mechanical Engineering and Ship Technology, Machinery and Materials Institute, Gdansk University of Technology, Gdańsk, Poland

2 Faculty of Mechanical Engineering and Ship Technology, Energy Institute, Gdansk University of Technology, Gdańsk, Poland

3 Department of Wood Science, Faculty of Wood Processing, Technical University in Zvolen, Zvolen, Slovakia 


\section{Introduction}

The energy consumption of the drying process is an important economical aspect in industrial production of wood products. Energy consumption in a conventional kiln is required for moisture evaporation, heating the kiln and lumber, kiln ventilation, thermal losses, air leakage and air humidification. Thermal energy consumption consists of three components: saw-timber warming up energy consumption, wood moisture evaporation power consumption, drying chamber railing energy losses. The main factor influencing the thermal energy consumption is the mode of saw-timber drying. The drying process requires delivering large amounts of thermal energy, which determines costs of sawmills production. Research in this field has a high importance for wood industry, because the industrial drying process requires constant development due to increased market demands and implementation of new wood products. Reduction in heat consumption and electricity (up to $35 \%$ ) for industrial dryer can be achieved, for example, by modifying the conventional drying process (Kininmonth et al. 1980; Salin 2004; Elustondo and Oliveira 2009; Ananias et al. 2012). For this purpose, calculations based on mathematical models (Dincer and Sahin 2004; Menshutina et al. 2004; Perré et al. 2007; Kudra et al. 2009; Elustondo and Oliveira 2009; Anderson and Westerlund 2012; Babich and Snopkov 2012) can be widely used in many different applications. The energy consumption reduction can also be achieved by setting, monitoring and adjusting selected parameters of the drying process (Shottafer and Shuler 1974; Wengert 1974; Elustondo and Oliveira 2006, 2007; Korkut et al. 2013). There are also wellknown measures that can be taken to reduce kiln energy consumption, such as the use of direct fired energy systems, installation of heat exchangers in kiln vents, partial air drying of green lumber, lumber preheating with kiln exhaust air, reduction in air flow velocity, lumber sorting before drying, and season planning. Depending on the case, only one or two of these strategies may be practical for a particular drying operation (Elustondo and Oliveira 2007).

One of the advantages of high-temperature wood drying, using superheated steam, is wood equilibrium moisture content reduction, which causes increasing drying speed up to 3.5 times compared to conventional drying process (Cai and Oliveira 2008). Furthermore, wood dried in superheated steam has increased resistance against degradation (Basilico et al. 1990; Frühwald 2007a; Frühwald 2007b; Volkmer et al. 2014; Esteves et al. 2014; Borrega and Kärenlampi 2010; SehlstedtPersson and Wamming 2010). On the other hand, disadvantages of high-temperature drying show up in reduced mechanical properties, for example, in the form of cracks (Oltean et al. 2007) in wood and specific, difficult drying process control (Stamm 1956; Kinimonth 1976; Dzurenda and Delijski 2000; Bekhta and Niemz 2003; Korkut and Budakçı 2009; Shahverdi et al. 2012; Barcík et al. 2014). Additionally, wood dried in high-temperature mode is more vulnerable to surface discoloration (McCurdy and Pang 2007; Möttönen and Kärki 2008; Ferrari et al. 2013; Németh et al. 2013) and in some cases resin leakages (Length and Sergeant 2008).

The creation of the mathematical model, which describes the heat energy requirement of the dryer must take into account mainly the heat exchange mechanisms 
between drying medium and dried wood (Górnicki et al. 2017). Other heat exchange mechanisms that have to be taken into account are between the dryer's construction and environment. The heat exchange mechanism between drying medium and dried wood is significantly different from conventional drying (where the drying medium is air or moisturized air, temperature of which does not exceed $100{ }^{\circ} \mathrm{C}$ at atmospheric pressure) and high-temperature drying (where bubbles of overheated steam are generated as a result of the temperature rise of the drying medium in the form of a mixture of air and superheated steam above $100{ }^{\circ} \mathrm{C}$, also at atmospheric pressure). The heat transfer mechanisms described in the literature during conventional drying (Krischer and Kröll 1959; Janik 1965; Häussler 1973; Shottafer and Shuler 1974; Krischer and Kast 1978; Vigants et al. 2015), based on energy balance, are used to determine the heat energy demand of a dryer, where the temperature of the humid air as the drying medium does not exceed $100{ }^{\circ} \mathrm{C}$. On the basis of these mechanisms, numerous mathematical models were developed to estimate heat consumption of the drying process (Anderson 1955; Shottafer and Shuler 1974; Ressel 1987; Čiegis and Starikovičus 2002; Elustondo and Oliveira 2009; Anderson and Westerlund 2012; Babich and Snopkov 2012), to optimize the drying process and the stress prediction model (Lessard 1978; Korkut et al. 2013). None of these models is applicable when the temperature of the drying medium exceeds $100{ }^{\circ} \mathrm{C}$ at atmospheric pressure. An attempt to develop mathematical models of high-temperature drying process is aimed at taking into consideration differences between these mechanisms and the study of drying medium parameters and dryer construction type impact on heat amount consumption and drying time respectively.

The main purpose of this study was to propose a modification of an existing mathematical model used to determine the heat consumption of a dryer during conventional drying (Dzurenda and Delijski 2010; Trebula and Klement 2005). The modified models will allow to determine the heat consumption and estimate the time of high-temperature drying, where the drying medium is a mixture of air and superheated steam. Two adjustments were introduced in the proposed mathematical model of the energy consumption of the drying process. The first one applies to drying time and introduces a coefficient taking into account the design of the dryer $\left(k_{5}\right)$. The second adjustment introduces an additional element $Q_{L}^{*}$ to the determined heat consumption in order to heat a mixture of air and superheated steam to evaporate water from the wood in the process of high-temperature drying (above $100{ }^{\circ} \mathrm{C}$ at atmospheric pressure). The obtained calculation results are compared with performed experimental tests of drying sapwood sawn timber (Pinus sylvestris L.).

\section{Theoretical background}

The mathematical model for technical standard (TZN) defines the total heat consumption for a technical drying process using hot air of $1 \mathrm{~m}^{3}$ of not frozen wood $\left(\mathrm{t}_{\mathrm{w}}>0^{\circ} \mathrm{C}\right)$ in a drying kiln at atmospheric pressure and at ambient temperature ranging from -20 to $35^{\circ} \mathrm{C}$. The process from initial moisture content $\mathrm{MC}_{\mathrm{P}}$ to final $\mathrm{MC}_{\mathrm{K}}$ is described by Eq. (1) (Dzurenda and Delijski 2009, 2010): 


$$
Q_{\mathrm{TZN}}=\frac{Q_{w}+Q_{V}+Q_{A}+Q_{L}+Q_{\mathrm{HG}}+Q_{S}}{V_{W}}\left[\frac{\mathrm{J}}{\mathrm{m}^{3}}\right],
$$

where

$Q_{\mathrm{TZN}}-$ Total heat consumption of drying process $\left[\frac{\mathrm{J}}{\mathrm{m}^{3}}\right]$,

$Q_{w}$-Heat consumption for heating wood in the dryer [J],

$Q_{v}$ - Heat consumption for heating up moisturized air in the drying kiln and moisturizing it during heating and equalization humidification phases $[J]$

$Q_{A}$ - Heat consumption for heating up the construction of the drying kiln and drying trolleys $[J]$,

$Q_{L}$ - Heat consumption to heat up the air in the dryer to evaporate water from wood [J],

$Q_{H G}$-Heat consumption for releasing hygroscopic water bound in wood [J],

$Q_{S}$ - Heat consumption to cover the heat loss of the dryer [J].

Trebula and Klement (2005) developed a methodology of the heat energy requirement of the dryer, which allows to extend the existing mathematical model to incorporate the additional part associated with heat energy generated in the drying kiln, caused by a fan operation and described by Eq. (2):

$$
Q_{\mathrm{TZN}}=\frac{Q_{w}+Q_{V}+Q_{A}+Q_{L}+Q_{H G}+Q_{S}+Q_{E}}{V_{W}}\left[\frac{\mathrm{J}}{\mathrm{m}^{3}}\right],
$$

where

$Q_{E}$-Heat generation by fans [J].

The heat demand (3) of the drying kiln takes into account the heat needed to heat up air or moisturized air to remove water from wood during the conventional drying process (drying temperature below $100^{\circ} \mathrm{C}$ at atmospheric pressure).

$$
Q_{L}=V_{W} \cdot \rho_{R} \cdot \sum_{i=1}^{n} q_{w_{i}} \cdot\left(\mathrm{MC}_{i}-\mathrm{MC}_{i+1}\right)[J],
$$

where

$V_{w}$-Volume of dried wood $\left[\mathrm{m}^{3}\right]$,

$\rho_{R}$-Reduced wood density $\left[\frac{\mathrm{kg}}{\mathrm{m}^{3}}\right]$,

$\mathrm{q}_{\mathrm{w}_{\mathrm{i}}}$-Specific heat consumption for evaporation of $1 \mathrm{~kg}$ of water in the i-step wood moisture content level $\left[\frac{J}{k g}\right]$,

$M C_{i}$-Wood moisture content in the i-step humidity level, when the drying air temperature does not exceed $100{ }^{\circ} \mathrm{C}\left[\frac{\mathrm{kg}}{\mathrm{kg}}\right]$,

$M C_{i+1}$-Wood moisture content in the (i+1)-step humidity level when the drying air temperature does not exceed $100{ }^{\circ} \mathrm{C}\left[\frac{\mathrm{kg}}{\mathrm{kg}}\right]$.

When the drying medium is air or moisturized air, whose temperature does not exceed $100^{\circ} \mathrm{C}$ at atmospheric pressure, specific heat consumption to remove $1 \mathrm{~kg}$ of water was determined using Eq. (4), (Trebula and Klement 2005): 


$$
q_{w_{i}}=\frac{h_{i}-h_{0}}{x_{i}-x_{0}}\left[\frac{J}{k g}\right],
$$

where

$h_{i}$-Specific enthalpy of air in drying kiln in the i-step humidity level of wood drying $\left[\frac{\mathrm{J}}{\mathrm{kg}}\right], h_{0}$-Specific enthalpy of air $\left[\frac{\mathrm{J}}{\mathrm{kg}}\right], x_{i}$-Air moisture content in the i-step humidity level of wood drying when the drying air temperature does not exceed $100{ }^{\circ} \mathrm{C}\left[\frac{\mathrm{kg}}{\mathrm{kg}}\right], x_{0 x_{0}}$-Air moisture content $\left[\frac{\mathrm{kg}}{\mathrm{kg}}\right]$.

To determine the specific heat consumption $\left(q_{w_{i}}\right)$, when the temperature of the drying medium does not exceed $100^{\circ} \mathrm{C}$ at atmospheric pressure, the Mollier diagram can also be used to create the so-called drying triangle (Dzurenda et al. 2013).

To determine the heat used to heat up the drying medium to evaporate water from wood $\left(\mathrm{Q}_{\mathrm{L}}\right)$ for a mixture of air and superheated steam, it was proposed to use Eq. (5):

$$
Q_{L}=V_{W} \cdot \rho_{R} \cdot \sum_{i=1}^{n} q_{w_{i}} \cdot\left(\mathrm{MC}_{i}-\mathrm{MC}_{i+1}\right)+Q_{L}^{*}[J],
$$

where

$Q_{L}^{*}$ - Heat used to heat up mixture of air and superheated steam to evaporate water from wood $[J]$.

The heat utilized to heat up the mixture of air and superheated steam to evaporate water from wood was determined by Eq. (6):

$$
\begin{aligned}
Q_{L}^{*}= & \left(m_{\mathrm{H}_{2} \mathrm{O}(w) *}+m_{\mathrm{H}_{2} \mathrm{O}(w a)}\right) \cdot\left(h_{s}-h_{w a}\right) \\
& +m_{\mathrm{H}_{2} \mathrm{O}(\mathrm{N})} \cdot\left(h_{s}-h_{\mathrm{H}_{2} \mathrm{O}(\mathrm{N})}\right)+m_{d a} \cdot\left(h_{d a(i)}-h_{d a(i-1)}\right)[J],
\end{aligned}
$$

where

$m_{\mathrm{H}_{2} \mathrm{O}(w) *}$-Water mass evaporated from wood during drying process at a temperature above $100{ }^{\circ} \mathrm{C}[\mathrm{kg}]$,

$m_{\mathrm{H}_{2} \mathrm{O}(\mathrm{wa})}$-Water mass in air for moisturizing period preceding drying process at a temperature of $100{ }^{\circ} \mathrm{C}[\mathrm{kg}], h_{s}$-Superheated steam enthalpy at a temperature above $100^{\circ} \mathrm{C}$ at pressure $p=101.3 \mathrm{kPa}\left[\frac{\mathrm{J}}{\mathrm{kg}}\right], h_{w a}$-Air specific enthalpy at temperature of the moisturizing period preceding drying at a temperature above $100^{\circ} \mathrm{C}\left[\frac{\mathrm{J}}{\mathrm{kg}}\right]$,

$m_{\mathrm{H}_{2} \mathrm{O}(\mathrm{N})}$-Drying medium moisturizing water mass from the steam generator, measured from the moment the drying medium temperature of $100{ }^{\circ} \mathrm{C}$ is reached $[\mathrm{kg}], h_{\mathrm{H}_{2} \mathrm{O}(\mathrm{N})}$ - Specific enthalpy of water in the steam generator $\left[\frac{\mathrm{J}}{\mathrm{kg}}\right]$,

$m_{d a}$-Dry air mass in the drying kiln $[k g], h_{d a(i)}$-Dry air specific enthalpy at a temperature above $100^{\circ} \mathrm{C}\left[\frac{\mathrm{J}}{\mathrm{kg}}\right], h_{d a(i-1)}$-Dry air specific enthalpy at a temperature for moisturizing period preceding drying at temperature of $100^{\circ} \mathrm{C}\left[\frac{\mathrm{J}}{\mathrm{kg}}\right]$.

The mass of evaporated water from wood during the drying process at a temperature above $100^{\circ} \mathrm{C}$ was determined by Eq. (7), which assumes a change in drying 
parameters from the moment the wood reaches moisture content at the fiber saturation point (FSP) level:

$$
m_{\mathrm{H}_{2} \mathrm{O}(w) *}=V_{D} \cdot \rho_{R} \cdot\left(\mathrm{MC}_{\mathrm{FSP}}-\mathrm{MC}_{F}\right)[\mathrm{kg}]
$$

where

$V_{D}$-Internal volume of the drying kiln $\left[\mathrm{m}^{3}\right]$,

$M C_{F S P}$-Wood moisture content for which the drying period begins at the drying medium temperature exceeding $100^{\circ} \mathrm{C}$, the work assumed $\mathrm{MC}_{\mathrm{FSP}}=15 \%$ (it is recommended that this value does not exceed the moisture content of wood at the fiber saturation point) [\%],

$M C_{F}$-Final wood moisture content $\mathrm{MC}_{\mathrm{F}}=8 \%[\%]$,

The water mass in air for the moisturizing period preceding drying at a temperature of $100^{\circ} \mathrm{C}$ was determined from Eq. (8):

$$
m_{\mathrm{H}_{2} \mathrm{O}(w a)}=\varphi_{w a} \cdot m_{w a}=\varphi_{w a} \cdot \rho_{w a} \cdot V_{w a}[\mathrm{~kg}],
$$

where

$\varphi_{w a}$-Air relative humidity in the moisturizing period preceding drying at a temperature above $100^{\circ} \mathrm{C}[\%]$,

$m_{w a}$-Air mass in the moisturizing period preceding drying at a temperature above $100^{\circ} \mathrm{C}[\mathrm{kg}]$,

$\rho_{w a}$ Air density at a given relative humidity and air temperature of the humidity period preceding drying at a temperature above $100^{\circ} \mathrm{C}\left[\frac{\mathrm{kg}}{\mathrm{m}^{3}}\right]$

$V_{w a}$-Air volume in the drying kiln $\left[\mathrm{m}^{3}\right]$.

The dry air mass in the drying kiln was determined from Eq. (9):

$$
m_{d a}=\frac{m_{\mathrm{H}_{2} \mathrm{O}(w a)}}{x_{w a}}[\mathrm{~kg}],
$$

where

$\mathrm{x}_{w a \_}$Air moisture content during the humidity period preceding the temperature rise above $100^{\circ} \mathrm{C}\left[\frac{\mathrm{kg}}{\mathrm{kg}}\right]$.

To determine the volume of air in the drying kiln, a simplified model was adopted, assuming that flue gas-air heat exchanger, the fan and electric motor occupy a volume of $15 \%$ of the drying kiln total volume, (10):

$$
V_{w a}=V_{D}-V_{W}-0,15 \cdot V_{D}\left[\mathrm{~m}^{3}\right]
$$

The specific drying time $\left(\tau_{A}\right)$, was calculated according to Eq. (11), which assumes correction of the calculated drying time by applying coefficients $\left(k_{1}, k_{2}, k_{3}\right.$ $\left.k_{4}\right)$, (Glijer 2005):

$$
\tau_{A}=\tau_{\mathrm{obl}} \cdot k_{1} \cdot k_{2} \cdot k_{3} \cdot k_{4} \cdot k_{5}[h],
$$

where

$\tau_{o b l}$ - Calculated drying time (Fig. 1) [h], 
$k_{1}$-Coefficient taking into account the difference in temperature used and the temperature $80{ }^{\circ} \mathrm{C}-90{ }^{\circ} \mathrm{C}[-]$,

$k_{2}$-Coefficient taking into account the speed of air flow through the wood stack $[-]$

$k_{3}$-Coefficient taking into account the type of sawmill material [-],

$k_{4}$-Coefficient taking into account the type of air flow through wood stack [-],

$k_{5}$ - Coefficient taking into account the drying kiln construction [-],

The values of the coefficients $k_{1}, k_{2}, k_{3}$ and $k_{4}$, used in the study, were in line with the results of the study by Glijer (2005): $k_{1}=1.55$ (for mild mode), $k_{1}=1.15$ (for normal mode), $k_{1}=0.79$ (for intense mode), $k_{2}=0.85$ (drying medium flow velocity between layers of wood species $v=2 \mathrm{~m} / \mathrm{s}$ ), $k_{3}=0.8$ (edged planks and logs shorter than $2 \mathrm{~m}$ ), $k_{4}=1.17$ (reversible circulation of the drying agent). In this work, an additional correction parameter of drying time is proposed, which takes into account the scale of drying, depending on the design and dimensions of the drying kiln by introducing empirically determined coefficient for semi-industrial dryer $k_{5}=0.9$ (for industrial dryer $k_{5}=1$ ).

The calculated drying time $\left(\tau_{o b l}\right)$ was determined using below formula (12) with determination factor $R^{2}=0.9921$, (Glijer 2005):

$$
\tau_{\mathrm{obl}}=-0.0052 \mathrm{MC}_{P}^{2}+1.5647 \mathrm{MC}_{P}-2.2213 \text {, for } 0<\mathrm{MC}_{P}<100
$$

An important drying parameter, which determines the quality of the drying kiln is the average specific heat consumption (q) required to evaporate $1 \mathrm{~kg}$ of water from dried material, which was calculated using Eq. (13):

$$
q=\frac{Q_{\mathrm{TZN}}}{m_{\left(\mathrm{H}_{2} \mathrm{O}\right) w}}=\frac{Q_{\mathrm{TZN}}}{V_{W} \cdot \rho_{R} \cdot\left(\mathrm{MC}_{0}-\mathrm{MC}_{F}\right)}\left[\frac{\mathrm{J}}{\mathrm{kg}_{\mathrm{ow}}}\right]
$$

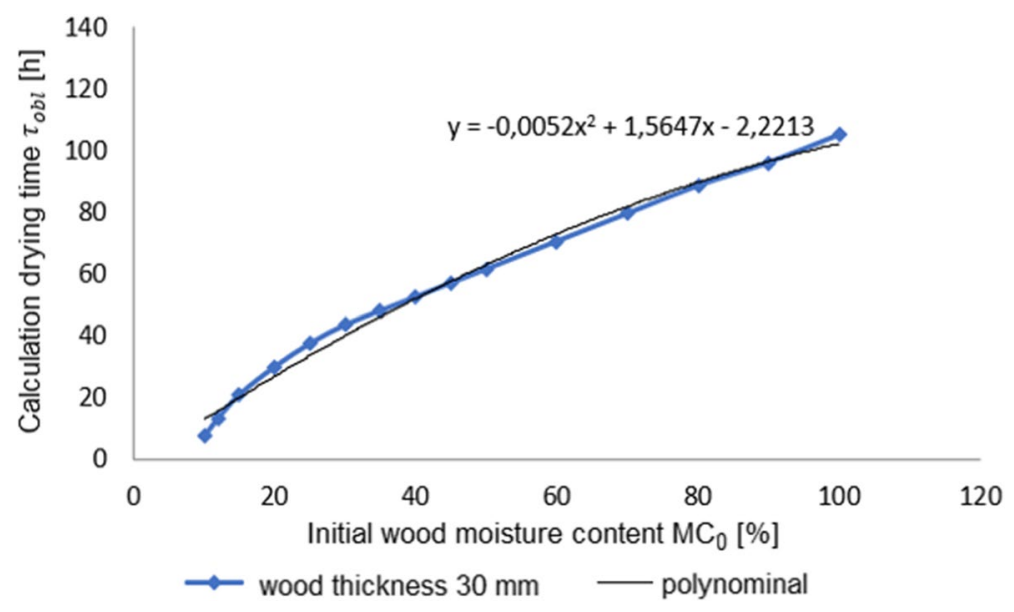

Fig. 1 Computational pine wood drying time for wood thickness $30 \mathrm{~mm}$ as a function of initial moisture content $\mathrm{MC}_{0}$ for air temperature $80-90{ }^{\circ} \mathrm{C}$ 
where

$m_{(\mathrm{H} 2 \mathrm{O}) \mathrm{w}}$-Water mass evaporated from wood [kg],

$M C_{0}$-Initial wood moisture content $\left[\frac{\mathrm{kg}}{\mathrm{kg}}\right]$.

According to generally available information in the literature, current average specific heat consumption used for drying kilns is in the range from 4500 to $5600 \mathrm{~kJ} / \mathrm{kg}$, (Trebula and Klement 2005).

Three drying modes, as the experimental studies of the drying process, were used to create a mathematical model of process energy consumption on semi-industrial scale. Calculated drying times are close to obtained real ones. This proves an appropriate selection of the coefficient proposed in this paper taking into account the design of the drying kiln $\left(\mathrm{k}_{5}\right)$ in order to correct the calculated drying time.

Total heat energy consumption, in Wh, was calculated using below formula:

$$
E_{C}=\frac{Q_{W}+Q_{V}+Q_{A}+Q_{L}+Q_{H G}+Q_{S}}{3600}[W h]
$$

\section{Materials and methods}

The results obtained after the calculations were compared with the conducted experimental test results of drying square-edged sawn sapwood timber (Pinus sylvestris L.), originating from the northern part of Pomerania region in Poland. Dimensions of all wood samples were measured prior to the experiments and featured $200 \mathrm{~mm}$ $(\mathrm{W}) \times 30 \mathrm{~mm}(\mathrm{H}) \times 1500(\mathrm{~L}) \mathrm{mm}$. The drying process was performed in a semiindustrial dryer using three drying modes: mild, normal and intense. The distinction into three different drying modes was made on the basis of temperature levels at which the process was carried out: low-temperature: $t<40{ }^{\circ} \mathrm{C}$, medium temperature: $40{ }^{\circ} \mathrm{C}<t<100{ }^{\circ} \mathrm{C}$, high-temperature: $t>100{ }^{\circ} \mathrm{C}$ (Trebula and Klement 2005). To ensure a correct and fast wood drying process in the drying kiln, the selected drying parameters (temperature and humidity of the drying medium) must meet the condition that equilibrium moisture content (EMC) should be lower than the wood moisture content (MC) in a given drying stage. This relationship is described by the drying gradient. The lower value of the EMC corresponds to the more intensive process of moisture evaporation from the wood. During each test, pine wood in the form of 24 boards was dried.

The drying process was conducted in an experimental, semi-industrial kiln of $0.55 \mathrm{~m}^{3}$ load capacity, especially designed at the Gdansk University of Technology (GUT) and manufactured by AMS-Elektronik Company. Internal dimensions were width $1.2 \mathrm{~m}$, depth $2.0 \mathrm{~m}$, height $0.7 \mathrm{~m}$, dryer weight $\mathrm{m}_{\mathrm{A}}=300 \mathrm{~kg}$, specific heat of dryer walls aluminum $\mathrm{c}_{\mathrm{A}}=0.9 \mathrm{~kJ} / \mathrm{kg} \cdot \mathrm{K}$, mineral wool: $\mathrm{c}_{\mathrm{A}}=0.75 \mathrm{~kJ} / \mathrm{kg} \cdot \mathrm{K}$. The drying kiln was equipped with a reversible fan made of cast iron, specific heat $\mathrm{c}_{\mathrm{Fe}}=0.55 \mathrm{~kJ} /$ 
$\mathrm{kg} \cdot \mathrm{K}$, (Neuhaus 2004). Based on these parameters, the drying kiln wall heat transfer coefficient was determined as $k_{\mathrm{P}}=0.23 \mathrm{~W} / \mathrm{m}^{2} \cdot \mathrm{K}$.

During the last phase of the intense mode drying process at a temperature of $120{ }^{\circ} \mathrm{C}$, the drying medium was moisturized with a steam generator and the amount of water in the generator was measured from the moment the temperature of $100{ }^{\circ} \mathrm{C}$ of the moistened medium was exceeded. The average mass flow rate of water in the steam generator was assumed at a level of approximately $1.5 \mathrm{~kg} / \mathrm{h}$.

\section{Results and discussion}

In Figs. 2, 3 and 4, changes in the relative humidity of the drying medium and its temperature and wood moisture content during the drying process on semi-industrial scale using three modes are presented. The initial moisture content of pine wood differs due to the date of fresh wood supply from the sawmill and depending on the drying mode used, because they present the experimental data on the basis of which the mathematical model of energy consumption was corrected by describing the drying curves with a quadratic function, which corrected the drying times obtained on a semi-industrial scale (by determining the $\mathrm{k}_{5}$ coefficient).

The obtained curves of pine wood drying in a semi-industrial dryer were described with high accuracy by exponential functions of second degree. It is noticeable that in all modes, wood moisture content calculation results are almost the same as the experimental results. This suggests that it is possible to use this equation to predict wood moisture content in each step of the process.

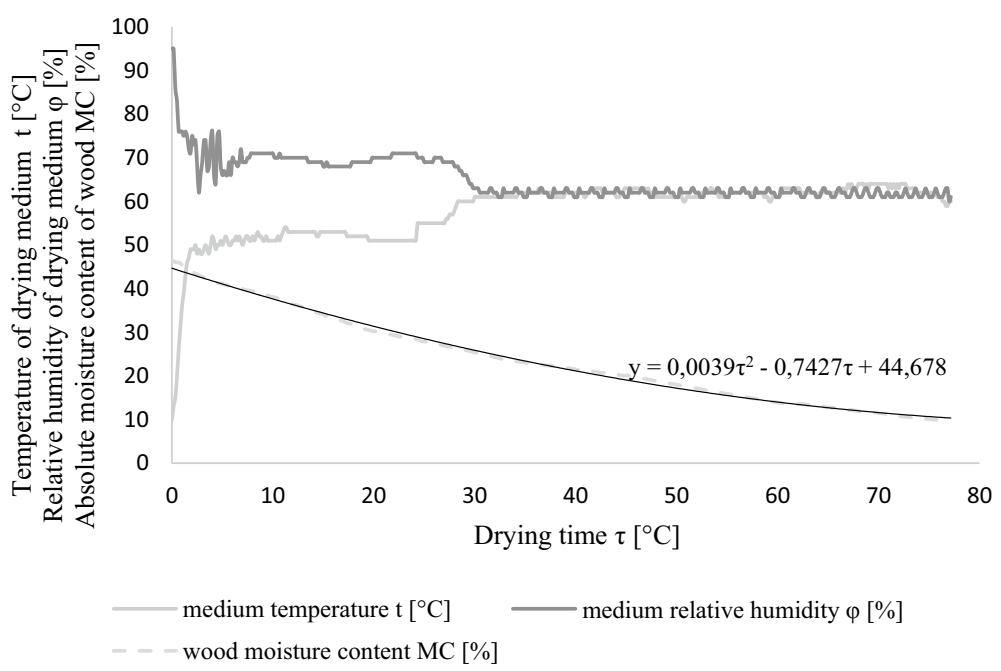

Fig. 2 Drying medium temperature, humidity and wood moisture content changes during mild mode drying process on semi-industrial scale 


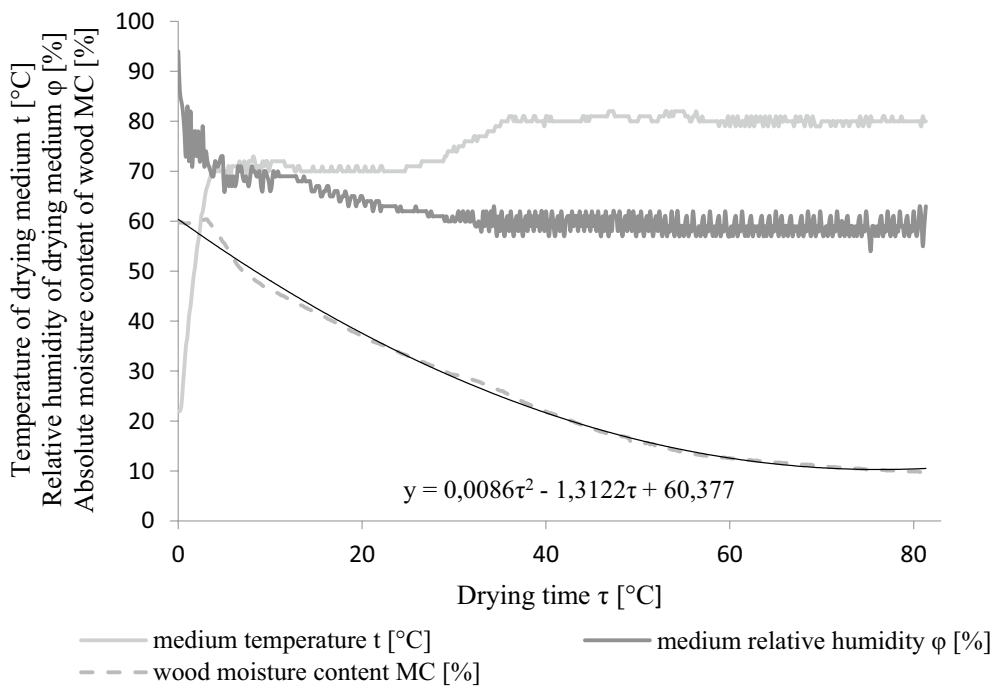

Fig. 3 Drying medium temperature, humidity and wood moisture content changes during normal mode drying on semi-industrial scale

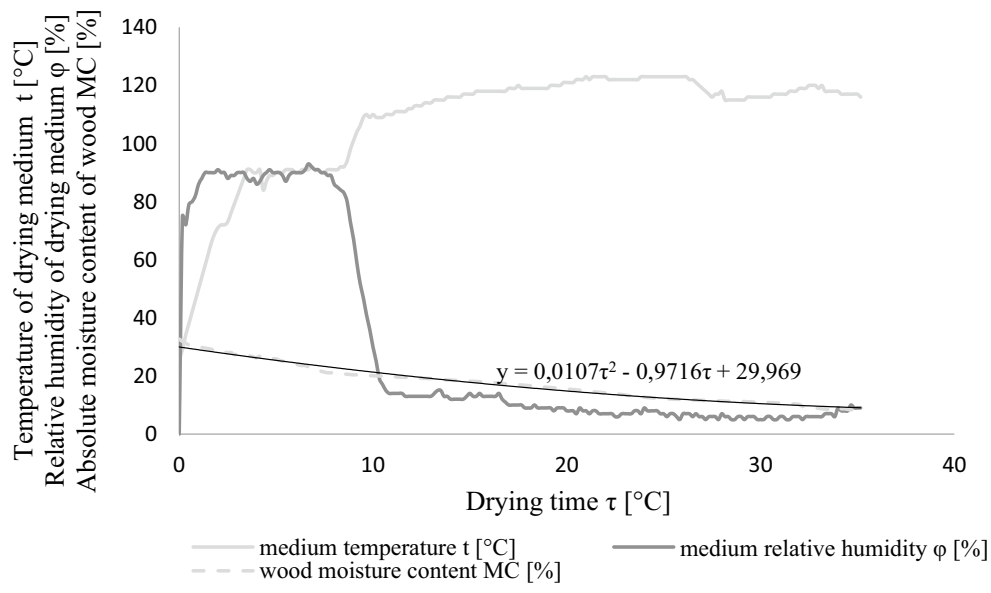

Fig. 4 Drying medium temperature, humidity and wood moisture content changes during intense mode drying on semi-industrial scale

To compare the most important parameters, which determine energy consumption of the semi-industrial drying process, i.e., unit heat consumption for evaporation of $1 \mathrm{~kg}$ of wood water $(q)$, heat consumption for heating drying medium $\left(Q_{L}\right)$, specific drying time $\left(\tau_{A}\right)$, total heat energy $\left(E_{C}\right)$ and electricity $\left(E_{w}\right)$ consumption, a simulation was carried out using the mathematical model presented above. The calculations took into account different initial wood moisture contents for the three drying modes used (Table 1). 
The calculations were carried out for drying medium flow velocity $v=2 \mathrm{~m} / \mathrm{s}$ (without the fan reverse mode). Temperature and relative humidity of the environment were $t=15{ }^{\circ} \mathrm{C}$ and $\varphi=75 \%$, respectively, at atmospheric pressure $p=101.3 \mathrm{kPa}$. Computational values were obtained for a final wood moisture content of $8 \%$. The loading volume of timber for each case was $V_{W}=0.216 \mathrm{~m}^{3}(24$ boards with dimensions: $200 \mathrm{~mm}, 30 \mathrm{~mm}, 1500 \mathrm{~mm}$ ). The initial wood temperature was adopted at ambient temperature level.

Figure 5 presents linear characteristics showing the total heat energy requirement of a semi-industrial drying kiln as a function of the pine wood initial moisture content from 80 to $30 \%$. It is noticed that the total heat energy consumption strongly depends on the wood initial moisture content. For mild and normal drying modes, the heat energy consumption is noticeably lower than for intense mode and is around $50 \%$ less. The heat energy consumption for mild and normal modes of the drying process is almost the same for higher values of wood initial moisture content and it is not much different for the lower values of wood initial moisture content.

The obtained determination coefficient $\left(R^{2}\right)$ in the range from 0.9982 to 0.9993 showed that the energy consumption of the drying process as a function of wood initial moisture content can be determined with the aid of a linear function with high accuracy.

For conventional chamber dryers, the value of the unit heat consumption $(q)$ ranges from 4490 (for low-capacity dryers) to $5690 \mathrm{~kJ} / \mathrm{kg}$ (for medium-capacity dryers) (Dzurenda and Delijski 2009; Elustrondo and Oliveira 2009; Anderson and Westerlund 2012). In the case of high-temperature drying $\left(t>100{ }^{\circ} \mathrm{C}\right)$, these values are two or even three times higher than in the case of conventional drying, while the drying time is significantly reduced (three to seven times) (Trebula and Klement 2005; Elustrondo and Oliveira 2009). All these relationships were demonstrated in the calculations performed. According to the technical classification standard for conventional chamber dryers, the value of total heat requirement $\left(\mathrm{Q}_{\mathrm{TZN}}\right)$ is approximately $680 \mathrm{MJ} / \mathrm{m}^{3}$, which corresponds to around $190 \mathrm{kWh} / \mathrm{m}^{3}$ for the

Table 1 Total drying times, total heat demand and energy consumption of the dryer depending on the initial moisture content for the three drying schedules used: $M C_{0}-$ wood initial moisture content, $Q_{T Z N}$ total heat requirement, $E_{w}$ - energy consumed by the fan, $N_{S}$-drying kiln heat output

\begin{tabular}{|c|c|c|c|c|c|c|c|c|}
\hline Mode & $\begin{array}{l}\mathrm{MC}_{0} \\
\%\end{array}$ & $\begin{array}{l}\mathrm{q} \\
\mathrm{kJ} / \mathrm{kg}\end{array}$ & $\begin{array}{c}\mathrm{Q}_{\mathrm{L}} \\
\mathrm{kJ}\end{array}$ & $\begin{array}{l}\tau_{\mathrm{A}} \\
\mathrm{h}\end{array}$ & $\begin{array}{l}\mathrm{Q}_{\mathrm{TZN}} \\
\mathrm{kJ}\end{array}$ & $\begin{array}{l}\mathrm{E}_{\mathrm{C}} \\
\mathrm{kWh}\end{array}$ & $\begin{array}{l}E_{w} \\
k W h\end{array}$ & $\begin{array}{l}\mathrm{N}_{\mathrm{S}} \\
\mathrm{W}\end{array}$ \\
\hline \multirow[t]{3}{*}{ Mild } & 80 & 4645.4 & $204,818.0$ & 90.8 & $274,529.6$ & 76.3 & 51.3 & 839.7 \\
\hline & 50 & 5224.1 & $112,417.4$ & 64.3 & $180,092.5$ & 50.0 & 42.3 & 777.5 \\
\hline & 30 & 6127.7 & $58,407.8$ & 41.5 & $110,652.3$ & 30.7 & 34.6 & 740.3 \\
\hline \multirow[t]{3}{*}{ Normal } & 80 & 4714.1 & $176,580.4$ & 68.8 & $278,593.8$ & 77.4 & 43.8 & 1124.3 \\
\hline & 50 & 5658.6 & $102,584.6$ & 49.2 & $195,070.6$ & 54.2 & 37.1 & 1101.7 \\
\hline & 30 & 7513.1 & $53,254.1$ & 32.3 & $135,668.7$ & 37.7 & 31.4 & 1168.3 \\
\hline \multirow[t]{3}{*}{ Intense } & 80 & 5978.4 & $209,583.4$ & 49.2 & $353,311.9$ & 98.1 & 37.1 & 1996.9 \\
\hline & 50 & 7935.7 & $140,653.3$ & 35.7 & $273,573.5$ & 76.0 & 32.6 & 2131.7 \\
\hline & 30 & $11,819.8$ & $94,699.9$ & 30.6 & $213,436.8$ & 59.3 & 30.9 & 1936.0 \\
\hline
\end{tabular}




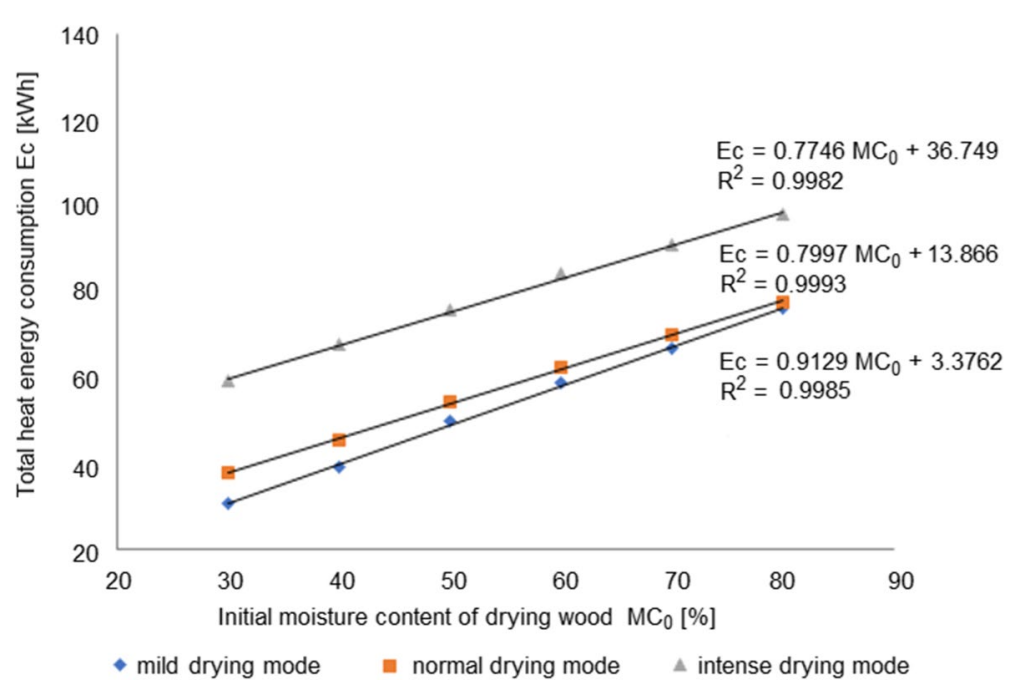

Fig. 5 Calculated total heat energy requirement of the semi-industrial drying kiln depending on the initial moisture content of wood for the three drying modes used: mild, normal and intense

low-temperature drying of softwood sawn timber with a thickness of $32 \mathrm{~mm}$, initial moisture content of $50 \%$, final moisture content of $10 \%$ and for medium capacity of the drying kiln KMC 121 (Dzurenda and Delijski 2009). The obtained total heat requirement $\left(\mathrm{Q}_{\mathrm{TZN}}\right)$ values for the tested semi-industrial dryer with a loading volume of $0.55 \mathrm{~m}^{3}$ pine wood and initial wood moisture content of $80 \%$ were $498.2 \mathrm{MJ} / \mathrm{m}^{3}$ (mild drying mode), $506.5 \mathrm{MJ} / \mathrm{m}^{3}$ (normal drying mode) and $642.4 \mathrm{MJ} / \mathrm{m}^{3}$ (intense drying mode). The obtained results confirm the correctness of the calculations of the proposed mathematical model of energy consumption for the pine wood drying process.

\section{Conclusion}

In this article, the results of theoretical analyses and an experimental research of pine wood (Pinus sylvestris L.) drying process are presented. The performed experiments allowed to develop a modified mathematical model of energy consumption of the drying process based on the models available in the literature. For this purpose, the correction of the drying process time by introducing the additional coefficient $k_{5}$ taking into account the design and construction of the drying kiln was proposed. In addition, the correction of the drying kiln heat requirement for the drying medium heating up stage to evaporate moisture from the drying material $\left(\mathrm{Q}_{\mathrm{L}}\right)$ for drying at a temperature above $100{ }^{\circ} \mathrm{C}$ was proposed.

On the basis of the accomplished analysis, it was found that the proposed mathematical model of energy consumption for high-temperature drying process can be used in the design of industrial dryers, enabling wood drying at temperatures exceeding $100{ }^{\circ} \mathrm{C}$ at atmospheric pressure, where the drying medium is an air 
and superheated steam mixture. After thorough analysis, it can be summarized that it is possible to estimate energy consumption and drying time of pine wood, taking into account initial wood moisture content, drying process parameters (coefficient $\mathrm{k}_{1}$ taking into account temperature of drying medium), drying medium flow rate (coefficient $k_{2}$ taking into account the velocity of air flow through the wood stack and coefficient $k_{4}$ accounting for the type of air flow through wood stack), sawn timber dimensions (coefficient $\mathrm{k}_{3}$ taking into account the type of sawmill material), drying kiln construction and design (coefficient $\mathrm{k}_{5}$ accounting for the drying kiln construction), and the amount of superheated steam supplied during the humidity period of drying at temperatures exceeding $100{ }^{\circ} \mathrm{C}$. In the study, the coefficients $k_{1}, k_{2}, k_{3}$, $k_{4}$ were adopted from the Glijer model (2005).

The developed mathematical model of the energy consumption of the high-temperature drying process introduces two adjustments: first one applies to drying time and introduces a coefficient taking into account the dryer design $\left(k_{5}\right)$. The second adjustment introduces an additional element $Q_{L}^{*}$ to the determined heat consumption in order to account for air and superheated steam mixture heat to evaporate water from wood during the high-temperature drying process (above $100{ }^{\circ} \mathrm{C}$ at atmospheric pressure). The chosen conditions of the drying process enable to estimate the energy consumption and duration of the drying process.

Acknowledgements Funding for this work was provided by the Polish National Agency for Academic Exchange (NAWA, Warsaw, Poland, Grant No. PPN/BIL/2018/1/00,162).

\section{Compliance with ethical standards}

Conflict of interest On behalf of all authors, the corresponding author states that there is no conflict of interest.

Open Access This article is licensed under a Creative Commons Attribution 4.0 International License, which permits use, sharing, adaptation, distribution and reproduction in any medium or format, as long as you give appropriate credit to the original author(s) and the source, provide a link to the Creative Commons licence, and indicate if changes were made. The images or other third party material in this article are included in the article's Creative Commons licence, unless indicated otherwise in a credit line to the material. If material is not included in the article's Creative Commons licence and your intended use is not permitted by statutory regulation or exceeds the permitted use, you will need to obtain permission directly from the copyright holder. To view a copy of this licence, visit http://creativecommons.org/licen ses/by/4.0/.

\section{References}

Ananias RA, Ulloa J, Elustondo DM, Salinas C, Rebolledo P, Fuentes C (2012) Energy consumption in industrial drying of radiata pine. Drying Technol 30:774-779. https://doi.org/10.1080/07373937. 2012.663029

Anderson J-O, Westerlund L (2012) Analysis of the heat demand in batch kilns. International IUFRO wood drying conference: 2012

Anderson R (1955) Wärmebedarf bei der künstlichen Holztrocknung unter Berücksichtigung der Wärmerückgewinnung bei der kontinuierlichen Trocknung (Heat requirement for artificial wood drying, taking into account the heat recovery for continuous drying), Holz Roh- Werkst 13(7):258-266 
Babich DP, Snopkov VB (2012) Thermal energy consumption at drying saw-timber in periodic convection drying chambers. Proceed BSTU Wood Woodwork Ind 2:96-99

Barcík Š, Gašparík M, Horejš P (2014) Influence of thermal modification on nail withdrawal strength of spruce wood. BioResources 9(4):5963-5975

Basilico C, Genevaux JM, Martin M (1990) High temperature drying of wood semi-industrial kiln experiments. Drying Technol 8(4):751-765. https://doi.org/10.1080/07373939008959913

Bekhta P, Niemz P (2003) Effect of high temperature on change in color, dimensional stability and mechanical properties of spruce. Holzforschung 57(5):539-546. https://doi.org/10.1515/HF.2003.080

Borrega M, Karenlampi PP (2010) Hygroscopicity of heat-treated Norway spruce (Picea abies) wood. Eur J Wood Prod 68(2):233-235. https://doi.org/10.1007/s00107-009-0371-8

Cai L, Oliveira LC (2008) Impact of high-temperature schedules on drying of spruce and pine. Drying Technol 26(9):1160-1164. https://doi.org/10.1080/07373930802266280

Čiegis R, Starikovičus V (2002) Mathematical modeling of wood drying process. Math Model Anal 7(2):177-190

Dincer I, Sahin AZ (2004) A new model for thermodynamic analysis of a drying process. Int J Heat Mass Trans 47:645-652

Dzurenda L, Delijski NS (2000) Changes of some mechanical properties of beech wood after steaming in autoclaves. Technická Univerzita vo Zvolene, Zvolen, Slovakia

Dzurenda L, Delijski N (2009) Matematický model výpočtu technicky zdôvodnitel'nej normy spotreby tepla na sušenia reziva v komorovej sušiarni (Mathematical model for calculation of the technical qualification norm of the heat energy consumption for drying of sawn wood in a drying chamber). Acta Facultatis Xylologiae 51(2):49-62

Dzurenda L, Delijski N (2010) Tepelné procesy v technológiách spracowania dreva (Thermal processes in wood processing technologies). Technická Univerzita vo Zvolene, Slovakia

Dzurenda L, Osipiuk J, Jabłoński M, Cyrankowski M (2013) Termodynamika Techniczna dla Drzewiarzy (Technical Thermodynamics for Woodworkers). SGGW, Warszawa

Elustondo DM, Oliveira L (2006) Opportunities to reduce energy consumption in softwood lumber drying. Drying Technol 24:653-662

Elustondo DM, Oliveira L (2007) Strategies to Reduce Energy Consumption in Kiln Drying. In Proceedings of the 10th International IUFRO Conference, Maine, USA

Elustondo DM, Oliveira L (2009) Model to assess energy consumption in industrial lumber kilns. Maderas Ciencia y tecnología 11(1):33-46

Esteves B, Nunes L, Domingos I, Pereira H (2014) Comparison between heat treated sapwood and heartwood from Pinus pinaster. Eur J Wood Prod 72(1):53-60. https://doi.org/10.1007/s00107-013-0751-y

Ferrari S, Allegretti O, Cuccui I, Moretti N, Marra M, Todaro L (2013) A revaluation of turkey oak wood (Quercus cerris L.) through combined steaming and thermo-vacuum treatments. BioResources 8(4):5051-5066

Frühwald E (2007a) Effect of high-temperature drying on properties of Norway spruce and larch. Holz RohWerkst 65(6):411-418. https://doi.org/10.1007/s00107-007-0174-8

Frühwald E (2007b) Effect of high-temperature drying and restraint on twist of Norway spruce. Drying Technol 25(3):489-496. https://doi.org/10.1007/s00107-007-0174-8

Glijer L (2005) Suszenie i parowanie drewna (Wood drying and steaming). Wieś Jutra, Warszawa

Górnicki K, Kaleta A, Bryś A, Winiczenko R (2017) Modelling of drying curves of spruce, beech willow and alder particles. Drvna Industrija 68(1):11-16

Häussler W (1973) Lufttechnische Berechnungen im Mollier - i-x Diagramm, 2. Auflage in der Reihe: Wärmelehre und Wärmewirtschaft in Einzeldarstellungen (Ventilation calculations in the Mollier - i-x diagram, 2nd edition in the series: Heat theory and heat management in individual representations). Verlag Theodor Steinkopff, Dresden

Janik W (1965) Handbuch der Holztrocknung (Wood drying handbook). VEB Fachbuchverlag Leipzig 1965:159-168

Kinimonth JA (1976) Effect of timber drying temperatures on subsequent moisture and dimensional changes. NZ J For Sci 6(1):101-107

Kininmonth JA, Miller W, Riley S (1980) Energy consumption in lumber drying. In Proceedings of the IUFRO Conference, Division V, Oxford, England

Korkut S, Budakçı M (2009) Effect of high-temperature treatment on the mechanical properties of rowan (Sorbus aucuparia L.) wood. Drying Technol 27(11):1240-1247. https://doi.org/10.1080/0737393090 3267161 
Korkut S, Unsal O, Kocaefe D, Aytin A, Gokyar A (2013) Evaluation of kiln-drying schedules for wild cherry wood (cerasus avium). Maderas-Cienc y Tecnol 15(3):281-292

Krischer O, Kast W (1978) Die wissenschaftlichen Grundlagen der Trocknungstechnik, 3. Auflage in der Reihe: Trocknungstechnik - Erster Band (The Scientific Basics of Drying Technology, 3rd Edition in a Series: Drying Technology - First Volume). Springer Verlag, Berlin

Krischer O, Kröll (1959) Trockner und Trocknungsverfahren (Dryer and drying process). Springer, Berlin, Göttingen, Heidelberg, pp 28-40

Kudra T (2004) Energy aspects in drying. Drying Technol 22(5):917-932

Kudra T, Platon R, Navarri P (2009) Excel-based tool to analyze the energy performance of convective dryers. Drying Technol 27:1302-1308. https://doi.org/10.1080/07373930903383687

Length C, Sergeant R (2008) Wood material behavior during drying: moisture-dependent tensile stiffness and strength of radiata pine at 70-150 ${ }^{\circ} \mathrm{C}$. Drying Technol 26(9):1112-1117. https://doi.org/10.1080/07373 930802266082

Lessard RA (1978) Modelling and controlling the lumber drying process. University of New Hampshire, $\mathrm{PhD}$

McCurdy MC, Pang S (2007) Optimization of kiln drying for softwood through simulation of wood stack drying, energy use, and wood color change. Drying Technol 25(10):1733-1740. https://doi.org/10. 1080/07373930701591077

Menshutina N, Gordienko M, Voynovsky A, Kudra T (2004) Dynamic analysis of drying energy consumption. Drying Technol 22(10):2281-2290. https://doi.org/10.1081/DRT-200039996

Möttönen V, Kärki T (2008) Color changes of birch wood during high-temperature drying. Drying Technol 26(9):1125-1128. https://doi.org/10.1080/07373930802266116

Neuhaus H (2004) Budownictwo drewniane (Wooden construction). Polskie Wydawnictwo Techniczne, Rzeszów

Németh R, Ott A, Takáts P, Bak M (2013) The effect of moisture content and drying temperature on the colour of two poplars and robinia wood. BioResources 8(2):2074-2083

Oltean L, Teischinger A, Hansmann C (2007) Influence of temperature on cracking and mechanical properties of wood during wood drying - a review. BioResources 2(4):789-811

Perré P, Rémond R, Aléon D (2007) Energy saving in industrial wood drying addressed by a multiscale computational model: Board, stack and kiln. Drying Technol 25:75-84. https://doi.org/10.1080/07373 930601160841

Ressel R (1987) Untersuchungen über den Energieverbrauch bei der technischen Schnittholztrocknung und Möglichkeiten zu dessen Verringerung (Investigation on the energy consumption during kiln drying of lumber and possibilities of its reduction). Universität Hamburg, Fachbereich Biologie, Diss

Salin, JG (2004) Determination of the most economical drying schedule and air velocity in softwood drying. In Proceeding of COST Action E15: Advances in Drying of Wood, Athens, Greece

Sehlstedt-Persson M, Wamming T (2010) Wood drying process: impact on Scots pine lumber durability. J Wood Sci 56(1):25-32. https://doi.org/10.1007/s10086-009-1066-9

Shahverdi M, Tarmian A, Dashti H, Ebrahimi G, Tajvidi M (2012) Mechanical properties of poplar wood (Populus Alba) dried by three kiln drying schedules. BioResources 7(1):1092-1099

Shottafer JE, Shuler CE (1974) Estimating heat consumption in kiln drying lumber. Life Sciences and Agriculture Experiment Station. Technical Bulletin no 73. University of Maine Life Sciences and Agricultural Experiment Station, Orono, Maine

Stamm AJ (1956) Thermal degradation of wood and cellulose. Ind Eng Chem 48(3):413-417

Trebula P, Klement I (2005) Sušenie a hydrotermická úprava dreva. 2 vyd. (Drying and hydrothermal treatment of wood. 2 ed.). Technická Univerzita vo Zvolene. Slovakia

Volkmer T, Lorenz T, Hass P, Niemz P (2014) Influence of heat pressure steaming (HPS) on the mechanical and physical properties of common oak wood. Eur J Wood Prod 72(2):249-259. https://doi.org/10. 1007/s00107-014-0777-9

Vigants E, Vigants G, Veidenbergs I, Lauka D, Klavina K, Blumberga D (2015) Analysis of energy consumption for biomass drying process. $10^{\text {th }}$ International Scientific and Practical Conference Environment Technology Resources. Rezekne, Lativa II:317-322

Wengert EM (1974) How to reduce energy consumption in kiln-drying lumber. U.S. Dept. of Agriculture, Forest Service, Forest Products Laboratory

Publisher's Note Springer Nature remains neutral with regard to jurisdictional claims in published maps and institutional affiliations. 